\title{
IMPACTS OF RELIGIOUS TOURISM IN JANAKPUR
}

Adhikari, Shyamchandra ${ }^{1}$

\begin{abstract}
The study of socio-economic impact of pilgrimage tourism in Janakpur shows the adverse effects in culture and environments. The study recommends to manage the devotee tourists more scientifically in top festivals. Many tourists are entering Nepal for religious purpose. This study has been concentrated on pilgrimage tourism and its socio-economic impacts in Janakpur area. Janaki mandir is one of the important religious sites of Nepal located in Dhanusha district which is around 234 KM far from the Kathmandu. In this connection how and why pilgrimage tourism brings socio economic changes in Janakpur area as well as what types of negative and positive impacts can be seen in the area. This study is based on both primary and secondary data and followed qualitative research design. For this study data were collected by using observation and individual questionnaires as data collection tools.
\end{abstract}

Keywords: Janakpur, Religions, Tourism

\section{Background}

Tourism is becoming popular in the world. It is the most important sources of economic development. Many countries are claiming it as the main sources of national income. From last few decades, tourism has been developing as an industry throughout the world. In the context of Nepal, tourism industry seems more beneficial than other industries. It is famous for artistic heritages, attractive scenes, geographical diversity, important religious spots, natural beauty, sights and socio-cultural diversities. It shows the unlimited potentiality for tourism development and its possibilities. Tourists move from place to place for different purpose. Among the various purposes, majority of people move for religious purpose. Nepal has long history about religious tourism. Hindu from India and Buddhist from China visit and have been visiting Nepal. So here are many religious spots, which are enough for the fulfillment to different objectives.

${ }^{1} \mathrm{Mr}$. Adhikari is a PhD Scholar of Trivuvan University on Rural Development.

Email: scrd2010@gmail.com 
Among them, Janakpur is one of the best sites of Nepal. Even though the history of Janakpur is very much older and it is one of the famous pilgrimages too for the Hindus. The mythological period covering the Treta Yugas, also contains numerous references regarding the temple, shrines and holy places of the country. Many reflections expressed in the ancient Hindu and Buddhist texts talked about the holiness of Nepal as the land of spiritual blessing and tranquility (Satyal, 2002). Nepal is generally known as the birth of Sita, Bhurkuti and Buddha. It is also known as the abode of Lord Shiva and the country of living Goddesses.

There are places of great natural beauty, medieval as culture with great mythological base such as Ram Janaki temple, Ram Janaki Vivaha Mandap, Dhanush Sagar, and Ganga Sagar in totals there are 52 ponds. To see these sites of supreme natural beauty one has to trek to Janakpur. Janakpur, the birth place of Sita is a sacred place for Hindus all over the world and stands on an equal footing with the holy places sacred to another world religious (Adhikari, 2017). The discovery of pilgrimage also shows that religious value, doctrines, and institutions have lost nothing of their status in and their influence over, every day behavior. This means that the modern individual is seeking transcendental values to overcome the fragments, the discontinuity, of modern society and that he or she is the Pilgrim tourist of modern times (Khanal, 2009).

The Himalayan Pilgrimages are the oldest organized travel system involved over time by Hindu Sages and embodying the spirit of wonder, adventure and spirituality. 'Tourism experts indicate towards a very interesting phenomenon that most backward regions abound, more often than not, in tourism and recreation resources, such as land aesthetics wilderness, archaeological ruins, ethnicity, indigenous crafts and folk culture. Tourism in such laggard regions can play a positive role in breaking through inertia and economic morbidity. As a catalyst, it can bring speedy socio-economic transformation of the society' (Kaur, 1985).

Nepal houses innumerable holy shrine of Hindu and Buddhist deities. The places of Hindu pilgrimage Janakpur, Muktinath, Baraha Kshestra, Gosain kunda, Swarga Dwari, Gorkha Manakamana are very famous and many devotees visit these places annually. In the same way, Buddhist places of pilgrimages such as Namo Buddha, Kapilvastu, Tauliglihawa, and other important Buddhist shrines and monasteries are 
scattered all over the country and many Buddhist devotees pay visit and make homage to Lord Buddha.

By going through the details given above, it is clear that Nepali culture is a mixture of two different civilizations of Asia, Mongoloid and Indo-Aryan culture Hinduism and Buddhism are both equally honored in Nepal and the assimilation of the two religious into one entity house created the distinct culture of its own. The fusion of Hinduism and Buddhism has given cementation of the spirit of religious tolerance. Any visitor can see a mixed breed with Buddhist stupa or monasteries and Hindu shrines or temples clustered close to one another in the courtyard of religious places. Nepal is really a Dev Bhomi (the land of gods and goddesses) and religious place has played an important role in modeling the outlook, attitude and custom of the people (Satyal, 2002)

In Nepal, tourism is recognized as second largest industry as the source of government revenue. It plays a significant role for economic development and environmental conservation. In fiscal year 2074/074 195 billion foreign currencies was earned which had given $7.8 \%$ contribution in GDP of the country (Aryal, 2005) (Economic Survey 2017).

People have been religious and spirituals oriented since time immemorial. They have religious tolerance and communalism among themselves. Religious synchronism has been the special characteristics from generation to generation. Hinduism and Buddhism flourished together without any discrimination and difference. So, these are thousands of pious places of pilgrimage in Nepal. Thousands of Nepalese go to several places of pilgrimage to neighboring country India. Likewise, millions of Indian pilgrims come to Nepal every year to pay thus homage to favorites God and Goddess. In this way the exchange of this type of religious visits increases which makes the age-old relationship between the two countries (Saran, 2017).

Hindu text Ramayana, Mahabharata, and other Hindu religious books have stated Janakpur as the birth place of goddess Janaki. Janaka was a famous king of Mithila. He was called Videha (Bodiless). His name was synonymous with wisdom and goodness. He was himself a great scholar. He ruled the kingdom of Mithila situated in southern Nepal for many years. But he had no children. One day, the childless Janaka sanctified the land and tilled it. He found a beautiful baby girl lying in a furrow. The word 'Sita' itself 
means furrow, the line made by the plough and is the name of a goddess associated with ploughed fields in Vedic literature. He bought her back to his royal place. She was brought up with great love and care and with all comforts. She was the paragon of beauty (Saran, 2017). Sita, regarded and respected by Hindus as a goddess because she was Lord Ram's dutiful consort, was born in Janakpur, then the capital of the ancient Mithila Kingdom. She is known by a number of other names as well.

She is Janaki or Janaka-Nandini, which means the daughter of king Janaka; Vaidehi, the daughter of Videha (bodiless Janaka); and Bhumija, meaning born from furrowed. Despite the hardships, Sita readily chose to accompany her husband into exile and serve him with the same humility and sacrifice when Ram was banished from his kingdom, Ajodhya, for 14 years. Ram did finally return to take over the reins of Ajodhya, but not before he and his wife went through her life, as a result, is the very symbol of truth (Satyam), good (Shivam) and Beauty (Sundaram). The saying "beauty is what beauty does" truly applies to Sita's character (Satyal, 2002).

Janakpur, Sita's parent's home, is proud to have given birth to such a virtuous person Sita. The headquarter of Dhanusha district, Janakpur in the south-east Terai of Nepal, is thus, naturally a place of immense religious and historical significance. Going back, Mithila was a legendary land a prominent artistic and cultural center in Asia. The kingdom was the center of Maithili culture and therefore, a store- house of artistic beauty and natural charm. The religious texts, the Vedas, the Ramayana, the Mahabharat are all manifestations of this culture.

Janakpur has kept culture in fact. Maithili culture still resonates in the many religious festivals that the people of Janakpur celebrate. Popular Maithili folk songs like Jhijhiya and Sama Chakwa songs, sung during the festival of Holi as well as marriage songs and many folk dances that reflect the rich culture of Mithila are still performed on different occasions. Janakpur is a historical and dating back to the great Hindu epic Ramayana. It is believed to be the place where fell broken remains of the Siva bow that Ram broke to obtain Sita's Hand for marriage.

A fossilized fragment of the broken piece is still believed to be seen and is worshiped by devotees. Also, Janakpur is the capital of ancient Mithila culture, and famous as the 
birth place of Sita believed to be incarnation of Goddess Laxmi of the Hindu mythology (Saran, 2017). It is also believed to be the place where lord Ram and Sita were married each other. There are several other pilgrimage sites in and around Janakpur area. Nepal Tourism Board For thousands of years, Sita has been the perennial source of inspiration of paintings and ancient art for the women of Mithila. The women over the years have cultivated the ceremonial art of drawing and painting on the mud walls of their houses. Now they are developing their ancient art on paper as form of prayer. The art of Mithila is mainly influenced by Tantric cults. So, the paintings are full of Tantric symbols (Saran, 2017).

\section{Research Question}

What is the socio- economic positive and negative impacts of pilgrimage tourism in Janakpur?

\section{Reviews}

Janakpur city is the birth place of Goddess Sita and it is the home of the unique Mithila culture in Nepal. Janakpur city, the headquarter of Dhanusha district of Nepal, is about 84 miles (235) km) from Kathmandu. Janakpur sub-metropolitan occupies 100.20 sq.km. This is the popular city in the Terai rigion. Janakpur is also known as Janakpur Dham (Dham in Nepali means a sacred region). It has temple name Janaki, which is dedicated to Goddess Sita. This region also offers an excellent opportunity for visitors to learn about Mithila culture, and people from in and around this peaceful region of Nepal. Hindu pilgrims from India and Nepal visit this region to pay their respect to the Goddess, while many foreigners make a side-trip to region to learn about the unique-life. Janakpur has the Janaki temple, which is dedicated to Goddess Sita and also has a Ram and Sita marriage Mandir or also known as Ram and Sita Vivaha Mandap which is said to have been built in the spot where they got married. Marriage anniversary of Ram and Sita is observed every year here through a festival which is also observed throughout Nepal.

In Janakpur region, one of such festival is the enactment of the wedding ceremony, decorating temples and monuments, burning of oil-lamps surrounding the temple and other historical sites in the region. Throughout the festival there rae dramas in theaters and in open streets re-making the marriage ceremony of Ram and Sita. According to 
Hindu, Ram and Sita took birth to free the earth from the cruelty and sins of the demon King Ravan (Adhikari, 2017). Janakpur is located in the Terai, alluvial, forested and marshy terrain at the base of the Himalaya mountain range. The major rivers surrounding Janakpur are Dudhmati, Jalad, Rato, Balan and Kamala Nadi. Janakpur is famous for its temples and the numerous ponds which carry significant religious importance. According to the Ramayan of Valmiki, Mithila and 'Vijji' were separate states. During the period of Buddha these two states emerged into a single state called 'Vijji' under the under the Lichhavis reign. During the period of the Gupta (377-437 B.S.) the territorial units of a state were called 'Bhukti' and it is because the state of Vaishali was located by the side of rivers. It seems that it started to be called 'Tira Bhukti'- a state located beside the river. The 'Mithila Mahatmaya', a book praising the glory of ancient Mithila has also given the same account. Round about eleventh century Kalingrya Purshottam in his work 'Trikandashesha' has described the word 'Tirabhukti' and 'Lichhavi' to be synonyms of 'Tirahuta' (Satyal, 2002).

The Vishnu Puran states that the topography of Janakpur is Kushaki in the west and Gandaki in the east extending up to 96 kos as from the Gangas in the south and the Himalayan forest in the north was extending to about 64 kos. This area is known as Mithila Bhumi (land of Mithila). One can see all the six seasons in Janakpur. Basantritu (Spring - February/March), Grismaritu (Summer - April/May/June), Barsharitu (Rainy July/August), Sharadritu (Autumn - September/October), Hemantaritu (Autumn-winter - November/December), Shishirritu (Winter - December/January). Temperature varies in winter is 3 to 10 degree and 30 to 42 degree in summer. The best time to visit Janakpur is from September to March as the weather is pleasant and several festivals fall during this period (Saran, 2017).

Mithila culture is found in the Terai region of Nepal such as the Janakpur region and also found all the way up to the Northern Bihar state of India. According to legend that Janakpur was the capital of Mithila, and the palace of King Janak, Goddess Sita's father. Often Sita is known by many names such as Janaki or Mythili. Mithila culture is rich with its own language known as Maithili, and with its own traditions, customs, arts and music. Many Mithila arts and paintings have historical and religious meanings, such arts are produced by many villagers specifically women's draw paintings having colorful and 
thought-provoking objects such as animals, Gods and Goddess which are painted on the walls of homes using simple colors such as clays and mud (Saran, 2017).

Jhula, Bol Bum, Ram Nawami, and Vivaha Panchami are important festivals which are celebrated with great pride and enjoyment along with other Nepali festivals such as Dashain and Tihar. During these festivals, the Janaki temple is packed with people. One other important festival is Chhath celebrated by Maithal is in Janakpur. It is a four days festival. A group of men and women dip in Ganga Sagar, a popular lake in the area, then worship the rising and setting of the sun for four days to receive blessings for peace and prosperity. Vibhaha Panchami, which falls between November and December, is a popular festival of Janakpur. The occasion commemorates the marriage of Sita to Ram, one of the most celebrated Hindu divinities. Janaki temple is the center of the attraction to commemorate this day and to celebrate the marriage anniversary of Ram and Sita. Thousands of pilgrims from India, Nepal and India pour into the region during this festival season.

Janakpur Dham have been the center of pilgrimage tourism since the down of Hindu civilization. It is like a Dham (pious place of pilgrimage). Janakpur has become a great pilgrimage site for Hindus today. The most sacred are the Janaki Mandir, dedicated to goddess Sita, the Ram Sita Bivaha Mnadir built over the spot where Ram and Sita were said to be married. Janakpur is not only famous for religious tourism but it is also the center of Mithila art and craft. Its artistic tradition is glorious. Janakpur has been rightly called a town of temple. There are so many ancient temples and artistic statues and shrines. There two temples which are popular and famous in the whole Hindu world. They are Janaki temple and Ram temple. Besides these two renowned temples there are numerous temples.

\section{Janaki Mandir}

Pilgrims flock here by the thousands to pay homage at the massive and magnificent Janaki Mandir. Janaki being the other name of Sita, the daughter of king Janaka. The temple was constructed in 1874 and is a blend of Mughal and local architecture at the cost of $15,00,000$. It was completed in 12 years. The temple is a three-story building and has 60 rooms, making it the largest temple in Nepal. The temple houses an ideal of Sita which 
was found near Ajodhya the kingdom of Ram. The marriage anniversary of Lord Ram and Sita is celebrated in Janakpur every year on Vivaha Panchami day which falls in December.

\section{Vivaha Mandap}

In the northeast corner of Janaki mandir is the Vivaha Manadap, which has built at the site where the marriage of Ram and Sita is said to have been taken place. Since then many marriage ceremonies have been taken there.

\section{Shree Sankatmochan Mandir}

This temple is dedicated to Hanuman, the most loyal attendant of lord Ram and Goddess Sita. This temple lies in the northwest corner of the mythological and called "Rangabhumi", is also known as "Barha Bigha" as it is 12 Bighas (1 Hectare=1.6 Bigha) in area. It was here that king Janaka arranged Dhanush Yagya or Bow-Breaking ceremony, in the Treata Yug.

\section{Rammandir}

Another well-known temple in the vicinity is Ram Mandir, a pagoda style temple built in 1882 which is located in south-east of the Janaki Mandir, which is different from other temple in Janakpur which generally bear resemblance to Mughal architecture. It houses a female status, said to be Yogmaya, which has the reputation of being one of the beautiful images of female forms in Nepal. Other holy site of interest includes the Laxman temple and Dhanush Dham, Mani Mandap.

\section{Ponds}

The Mithila region prides itself in having a large number of ponds. Janakpurdham is said to have as many as 115 ancient ponds of historical and mythological importance. Among The ponds, Gangasagar, Parshuramkunda, Dhanushasagar, Argazapokhari, Ratnasagar, Biharkunda, Chittaradharsagar, Bhargavasagar, Gopalsagar are held as extremely sacred.

\section{Methodology}


This study concentrates on religious tourism of Janakpur temple. For this study both primary and secondary data were used and these data were obtained by using individual questionnaires and observation. Individual questionnaires were asked to 20 tourists including domestic, Indian, regional, and another foreigner. In the same way 20 local households were selected. People are living in Janakpur area for long time. They directly faced both negative and positive impacts of the tourism. Only 20 respondents (each household single respondent) were randomly select for this study and asked question related to socio economic impacts of the tourism. More than that researcher also visited the area and observed the socio-economic situation of the people living in the area and directly affected due to Religious tourism. Collected data were analyzed by using qualitative research design because the study only describes the situation without using any mathematical and statistical tools.

\section{Discussion /Analysis}

Flow of tourist increased day by day after the Indian prime minister Narendra Modi's religious visit in Janakpur. Most of the tourists have visited Janakpur for religious purpose; however, some of them visit Janakpur due to fun with side seeing. The flow of tourist in Janakpur during 2017 January to December high during the period of festival like Ramnawami, Janaki Nawami, Vibha Panchami,Chhath,Dasain, Dipawali and foreign tourist are minimum in the Janakpur.

\section{Duration of the Stay}

The amount of expenditure of tourist mainly depends upon length of stay of tourist in the tourist spot or in the country. Below table illustrates distribution of tourists by the duration of stay not in study area but in Nepal.

Table: 1 Distribution of Tourist by the Duration of Stay

\begin{tabular}{|l|c|c|}
\hline \multicolumn{1}{|c|}{ Length of the Stay (Days) } & No. of Tourist & Percentage \\
\hline Returned on the same day & 11 & 55 \\
\hline Stayed 1 day & 5 & 25 \\
\hline 2days and more & 4 & 20 \\
\hline Total & 20 & 100 \\
\hline
\end{tabular}

(Field Survey, 2018) 
The above table shows that 55percent of tourist was found not stayed in Manakamana site. Around 25percent tourist were found stayed for a day while 20percent tourist were recorded stayed for 2 or more than 2 days. This table shows the fall down in the number of tourists lived in destination.

\section{Expenditure of Tourists}

Tourism is a lucrative business that plays very crucial role in the economic development of a nation. More economic benefit can be acquired with the longer stay of the tourists in the destination. Thus, the amount of expenditure of the tourists is mainly determined by their length of stay in tourist spot and in the country. The below table clears the expenditure done by tourists in the temple Area.

Table: 2 Distributions of Tourists According to Their Expenditure:

\begin{tabular}{|l|c|c|}
\hline Expenditure in Rs & No. of Tourist & Percentage \\
\hline Below Rs.1000 & 2 & 10 \\
\hline Rs.1000- Rs 2000 & 10 & 50 \\
\hline Above Rs.2000 & 8 & 40 \\
\hline Total & 20 & 100 \\
\hline
\end{tabular}

(Field Survey, 2018)

The above table shows that the highest 50 percent expenses was in between Rs. 1000 to Rs.2000 while the lowest 10percent had in below Rs 1000. Among total respondents 40percent, tourists' speculated expenditure in the study area was above Rs. 2000.. It shows that the amount of expenses of tourist in the temple site is not much high in comparison to other tourist spots because of lack of the required entertainment facilities in the area or due to lack of tourist stay in hotels.

Purpose of Visit of Tourist

It is the purpose of visit that motivates tourists to travel from one place to another place. People visit area with different purposes such as general visitors, research study, pilgrimage, to see the traditional culture etc. The below table shows the purposes of tourist 
come to visit the Durbar Square Area.

Table: 3 Distributions of Tourists by the Purpose of Visit

\begin{tabular}{|l|l|c|c|}
\hline SN & \multicolumn{1}{|c|}{ Purpose of Visit } & No. of Tourist & Percentage \\
\hline 1 & Pilgrimage & 12 & 60 \\
\hline 2 & Research Study, to see the Mediaeval Art \& Architecture & 1 & 5 \\
\hline 3 & Recreational Visit & 7 & 35 \\
\hline & Total & 20 & 100 \\
\hline
\end{tabular}

(Field Survey, 2018)

The above table illustrates that out of 20 respondents 60percent of tourist came because of religious purposes where as 35 percent were came as recreational visitors. It was found that 5 percent of tourist were for research study. This table clearly shows that the volume of tourists came for religious activities were higher than other purpose in the study area.

Main Problems faced by the visitors

When the visitors were asked for the problems faced by them during their visit, visitors expressed their problems in different sector as listed in the table below.

Table: 4 Main Problems faced by the visitors

\begin{tabular}{|l|l|c|c|}
\hline $\begin{array}{l}\text { S. } \\
\mathrm{N}\end{array}$ & Main Problem & No of visitors & Percentage \\
\hline 1. & Highly Expensive & 8 & 40 \\
\hline 2. & Accommodation & 4 & 20 \\
\hline 3. & Transportation & 3 & 15 \\
\hline 4. & Security & 4 & 20 \\
\hline 5. & Others & 1 & 5 \\
\hline & Totals & 20 & 100 percent \\
\hline
\end{tabular}

(Field survey, 2018)

The above table shows that main problems faced by the visitors, where 40 percent of respondents found that visiting the sites was highly expensive, followed by the 20 percent respondents felt that the site was lacked of enough and satisfactory accommodation 
Research Nepal Journal of Development Studies (Year $1^{\text {st }}$ Issue $2^{\text {nd }}, 2018$ November)

facilities. 15 percent of respondents said that the transportation facilities was not satisfactory. Similarly,10 percent of respondents was felt that advertisement was problem for their self-preparedness and another 10 percent of respondents felts that security seems lacking while 5 percent respondents said about others problems in the site.

Socio Economic Characteristics of the Respondents

Around the temple area there were closed settlement. Among them only 20 house hold (ie15percent) respondents have randomly taken for the interviews. Socio economic status of the respondents such as age, sex and religious status are highlighted in the following tables.

\section{Table: 5 Distributions of Respondents by Age and Sex}

\begin{tabular}{|c|c|c|c|c|c|c|}
\hline \multirow[t]{2}{*}{ Age } & \multicolumn{4}{|c|}{ Sex } & \multirow[t]{2}{*}{ Total } & \multirow{2}{*}{$\begin{array}{c}\text { Total } \\
\text { Percentage }\end{array}$} \\
\hline & Male & $\%$ & Female & $\%$ & & \\
\hline Below 15 Years & 1 & 5 & 2 & 10 & 3 & 15 \\
\hline 16-59Years & 7 & 35 & 6 & 30 & 13 & 65 \\
\hline 60 Years and above & 2 & 10 & 2 & 10 & 4 & 20 \\
\hline Total & 10 & & 10 & & 20 & 100 \\
\hline
\end{tabular}

(Source: Field Survey, 2018)

The above table shows the fact that proportion of male tourist and female are equal in no. in visiting the temple. Economically active group (16 to 59) years are the most respondents of the temple ( 65 percent) followed by 60 years and above age people and

Table: 5 Educational levels of Respondents

\begin{tabular}{|c|c|c|c|}
\hline $\mathrm{SN}$ & Education & Respondents & Percentage \\
\hline 1 & Illiterate & 2 & 10 \\
\hline 2 & Literate & 18 & 90 \\
\hline & Total & 20 & 100 \\
\hline
\end{tabular}

(Source: Field Survey, 2018)

Education status of the respondents play vital role to involvement in tourism related activities. Above table shows the education status of the respondents and shows 10 percent are illiterate and 90percent are literate. 
Table: 6 Occupational Statuses

\begin{tabular}{|c|l|c|c|}
\hline SN & \multicolumn{1}{|c|}{ Occupation } & Respondents & Percentage \\
\hline 1 & Agriculture & 9 & 45 \\
\hline 2 & Tourism Sector and business & 7 & 35 \\
\hline 3 & Labor & 2 & 10 \\
\hline 4 & Others & 2 & 10 \\
\hline & Total & 20 & 100 percent \\
\hline
\end{tabular}

(Source: Field Survey, 2018)

The above table shows that the main occupation of the respondents' data shows that 45percent. Respondents involve in agricultural activities except business. 35percent. Only involve in tourism related activities where as 10 percent of respondents was working as a labor and next 10 percent of respondents replied for other occupations except tourism related activities such as foreign job, service etc.

Socio economic Impacts of tourism in Janakpur

Most of the visitors were for the pilgrimage purpose. When asked about the positive and negative impacts on cultural sector due to tourism visiting the temple, the most of the people have not properly commented. While analyzing economic impacts of religious tourism in Janakpur 40 percent of respondents said that their income was increased by 50 percent, 40percent respondents replied that income was increased by 25 percent whereas 10percent respondents replied that their income was raised above 10percent than before due to the tourism activity. Selling of arts and photos to the visitors was the main item which had helped to increases the income level of the small entrepreneurs in the study area (40 percent) while selling of vegetable accounted raised in income by 30percent. 35 percent of the respondents were satisfied that the tourism entrepreneurs are able to support the local economy where as 50percent of respondents said that it is good enough.

When the respondents were asked about the positive and negative impact situation on social sector like health, education, water, effects in moral and social values, involvement of people in social work, women and child condition of temple sites, respondents replied in three different scenarios.

Table: 7 Impact situations in social sector (Positive / Negative in \%) 


\begin{tabular}{|c|l|c|c|c|}
\hline S. N & Social Sector & Negative impact & Positive impact & $\begin{array}{l}\text { Same as } \\
\text { before }\end{array}$ \\
\hline a. & Health service facilities & - & 20 & 80 \\
\hline b. & Educational awareness & 25 & 55 & 20 \\
\hline c. & Drinking water facilities & 15 & 25 & 60 \\
\hline d. & $\begin{array}{l}\text { Growth in moral \& social } \\
\text { values }\end{array}$ & 10 & 35 & 55 \\
\hline e. & $\begin{array}{l}\text { Involvement of people in } \\
\text { social work }\end{array}$ & 15 & 55 & 30 \\
\hline f. & Women and child condition & 25 & 60 & 15 \\
\hline
\end{tabular}

(Field survey, 2018)

The above table shows that 80percent respondents of study area felt that Health service facilities was same as before whereas only 20percent felt that there was positive impact. So, it is felt that health service facilities of the area need major improvement. More than the half of study area people asked said that the temple have brought positive impact in educational awareness.60 percent people think that drinking water facilities have not improved besides the taps. Likewise, positive impact was seen in the people's involvement in the social work. Similarly, positive impact was seen in women and children condition than before by 60 percent

\section{Cultural Sector}

When the HHs respondents were asked about the positive and negative impacts on different cultural sector like conservation of tradition culture like festivals, religions, dress up, change in behavior and attitude like habits, way of thinking, social crimes, etc. and any change in the life style, respondents have not properly commented.

The given table shows that percentage of sample household reporting on cultural sector.

Table no: 8 Household Reporting on Cultural Sector (positive/ Negative)

\begin{tabular}{|c|l|c|c|}
\hline S N & Cultural Sector & Negative impacts & Positive impacts \\
\hline a. & $\begin{array}{l}\text { Conservation of } \\
\text { tradition culture }\end{array}$ & 45 & 55 \\
\hline
\end{tabular}




\begin{tabular}{|c|l|c|c|}
\hline b. & $\begin{array}{l}\text { Change in Behavior and } \\
\text { attitude }\end{array}$ & 35 & 65 \\
\hline c. & Life style & 60 & 40 \\
\hline
\end{tabular}

(Field survey, 2018)

The above table shows that the most of the people have believed that the site has been conserved while 45percent respondents expressed that the tradition and culture has been deteriorated. 65percent respondents agreed that their behavior and attitudes has been changed due to interaction of locals with tourists.

\section{Impact on Economic Condition}

Agriculture is the main economic activity of the people in Janakpur besides small entrepreneurship of local goods and products. The economic condition of the people here can be stated as moderate without any such hardships compared to the people in other parts of the country. The positive and negative economic impact situation can be analyzed with the question asked in the subheads below

Household Income Situation

When local household people were asked about the income situation by selling the different local product to the local entrepreneurs as pilgrimage destination, respondents were satisfied that their income level was increased by some sort of percentage.

\section{Table no: 9 Households income situation}

\begin{tabular}{|c|l|c|c|}
\hline SN & Increased income by & Respondents & Percentage \\
\hline 1 & 10 percent & 2 & 10 \\
\hline 2 & 25 percent & 10 & 50 \\
\hline 3 & 50 percent & 8 & 40 \\
\hline & Total & 20 & 100 percent \\
\hline
\end{tabular}

(Field survey, 2018)

The above table shows that the highest percentage of household's (50percent) income increased in the range of 25 percent and 40 percentage of household's income increased in the range of 50 percent and 10 percentage household's income was increased by 
10 percent only. Thus, we come to conclusion that tourism has definitely increased the economic activities in the Janakpur.

\section{Entrepreneurs Income Situation}

When the entrepreneurs were asked about the goods that had helped them to increase their income level, they were convinced their income level was increased by selling different goods like vegetables, Pickles, Arts and photos with frameset etc. to the tourists.

Table no:10 Entrepreneurs income situation

\begin{tabular}{|c|c|c|c|}
\hline $\mathrm{SN}$ & Products & Respondents & Percentage \\
\hline 1 & Vegetables & 6 & 30 \\
\hline 2 & Pickles & 5 & 25 \\
\hline \multirow[t]{3}{*}{3} & Arts and photos with frameset & 8 & 40 \\
\hline & Others & 1 & 5 \\
\hline & Total & 20 & 100 percent \\
\hline
\end{tabular}

(Field survey, 2018)

The above figure shows that respondents reporting increased in income by selling of arts and photos is highest(40percent), followed by vegetables(30percent) but however increased income due to selling of others products only seems to be only 5 percent.

Support on Local Economy by Tourism Entrepreneurs

When the tourism entrepreneurs were asked on the different range supporting the local economy due to the tourism entrepreneurship, the find out of those questionnaires was found as per the table below.

Table 11: Support on local economy due to tourism entrepreneurs

\begin{tabular}{|l|l|c|c|}
\hline SN & Range & No of Respondents & Percentage \\
\hline 1 & Good & 10 & 50 \\
\hline 2 & Satisfactory & 7 & 35 \\
\hline 3 & Very minimal & 3 & 15 \\
\hline & Total & 20 & 100 percent \\
\hline
\end{tabular}

(Field survey, 2018) 
The above table indicates that the 35percent of the respondents were Satisfied that the tourism entrepreneurs are able to support the local economy where as highest 50percent of respondents said that it was good enough. But, 15percent respondents answered supports on local economy due to tourism entrepreneurs was very minimal.

Employment Generated by the Local Entrepreneurs

When the Hotels and small entrepreneurs were asked about the employment generated due to the tourism around temple site most of the respondents agreed that the tourism activity has created the employment opportunity mostly for the local people and said that tourism has helped to raise the economic status of poor people in the locality.

Table 12: Employment Generated by the local entrepreneurs

\begin{tabular}{|c|c|c|c|}
\hline SN & Staff & No of Respondents & Percentage \\
\hline 1 & Local & 12 & 60 \\
\hline 2 & Outsider & 4 & 20 \\
\hline 3 & Both local and outsider & 4 & 20 \\
\hline & Total & 20 & 100 percent \\
\hline
\end{tabular}

(Field survey, 2018)

The above table shows that 60percent of local people were getting the employment opportunities followed by 20percent of people from outside the local area and other 20percent employee compromises both from the local area as well as from the outside as per the respondents.

Facilities Available in the Hotels Entrepreneurs

When the hotels entrepreneurs were asked about the accommodation facilities, some of them said that both the lodgeing and fooding facilities were available but other said that only fooding facilities was available.

Table No 13: Facilities Available in the Hotels Entrepreneurs

\begin{tabular}{|l|c|l|l|}
\hline SN & Hotels Entrepreneurs & Accommodation & Percentage \\
\hline 1. & 1 & Lodging \& Fooding & 40 \\
\hline 2. & 3 & Fooding only & 60 \\
\hline
\end{tabular}




\begin{tabular}{|l|l|l|l|}
\hline & Total $=4$ & & 100 percent \\
\hline
\end{tabular}

(Field survey, 2018)

The above table shows that 40percent of hotels entrepreneurs are able to provide both lodging and fooding facilities where as 60percent hotels entrepreneurs are able provide only fooding facilities.

\section{Findings/Conclusion}

Tourism industry is becoming an important source for earning foreign exchange and employment generation industry in the world, and Nepal is not far away of that fact. Every year millions of tourists visit Nepal from different countries for different purpose. Among them, pilgrimage tourists are playing important role in tourism industry. Here are very important religious places so Nepal is called as a home of Gods and land of festivals. Among them Janakpur is one of the important religious places for Hinduism. This study mainly focuses on the problems and prospects of religious tourism in the Janakpur Region. It is hope that, it will be useful for different individuals and organize institution. This study was mainly based on the primary data but some essential information where taken from different publications, articles, books dissertations of related field. Similarly, different methods were used to conduct this study. Local people of Janakpur, tourists, hotel and restaurant owner and well-known person about Janakpur.

Janakpur is good for productive land, economic condition and literacy rate. Mainly Yadav, Sah, Jha, Gupta, Kayesta, Mallah, Chhetri, Bramhan, Musahar, Dom and Muslim are living in Janakpur. Ram Janaki Mandir, Vivaha Mandap, Ram Mandir, Ganga Sagar, Dhanush Sagar, Sankatmochan Mandir, the Sacred Ponds are the important places of Janakpur. Dashain, Tihar, Chhat, Holi are the main festivals of Janakpur.

70 percent of the tourist visited Janakpur by public bus while others visited by private car, reserved car and on foot. Janakpur is one of the top five cities of the Nepal though, but there is no sufficiently available of the facilities and services, so tourist do not want to live long duration. Different tourists visited for different purposes but most of them have religious faith. Religious faith scenic attraction, many temples and environment are the main prospects of tourism development in Janakpur. Mainly security, communication, 
water supply, accommodation, health service and recreational, transportation, facilities are the main problems of Janakpur for tourism development. Finally, socio economic impact is positive although scientific management of pilgrims or tourists is most.

\section{References}

Adhikari, S. (2017). Hindu pilgrimages in Nepal. The next Era vol.3 , 22-39.

Aryal, D. (2005). Economic Impact of Tourism in Nepal: Kirtipur. . Kirtipur: Central Department of Economics TU.

Kaur, J. (1985). Himalayan Pilgrimages and the New Tourism. Delhi: Adroiwt Publications.

Khanal, P. (2009). An Assessement on Prospect of Religious Tourism in Nepal: A case study of Lumbini in Rupandehi District. . An unpublished dissertation, Central Department of Rural Development, T.U, Kirtipur,Kathmandu,Nepal.

Saran, S. (2017). Janakpur Dam. Janakpur: Shree Janaki books store.

Satyal, Y. R. (2002). Pilgrimage Tourism In Nepal. Delhi: Adroit Publisher. 